\title{
PROTECTION AREAS OF THE SAN JUANITO META MUNICIPALITY, A LOOK FROM LOCAL DEVELOPMENT
}

\section{CASTRO GARZÓN HERNANDO ${ }^{1}$, RODRÍGUEZ MIRANDA JUAN PABLO ${ }^{2} \&$ RIVAS TRUJILLO EDWIN $^{3}$}

${ }^{l}$ Profesor. Escuela de Administración y Negocios. Facultad de Ciencias Económicas, Universidad de los Llanos, Villavicencio, Colombia

${ }^{2}$ Profesor Titular. Facultad del Medio Ambiente y Recursos Naturales. Universidad Distrital Francisco José de Caldas. Bogotá, Colombia

${ }^{3}$ Grupo de Investigación Interferencia Electromagnética (GCEM), Ingeniería Eléctrica, Facultad de Ingeniería, Universidad Distrital Francisco José de Caldas, Cra 7 No 40B-53, Bogotá, Colombia

ABSTRACT
It arises a job that used a qualitative method, of descriptive type, with a design focus Participatory Action Research; It
was addressed to holders or owners of premises inserts in the National Natural Chingaza Park
(PNNCH) on jurisdiction of San Juanito Meta municipality; Semi-structured interviews were carried out to identify the
influence of the adoption of Protected Areas on local development. It was obtained as a result that the community it is
vulnerable to processes of theft of territories by the nation for conservation purposes; On the other hand, the
potential expansion of zones with a damping function puts pressure on it. Concluding that it is necessary
to assume productive reconversion processes to ensure permanence in the rural area of the municipality.
KEYWORDS: Municipality, Local Development \& Protection

Received: Jun 08, 2020; Accepted: Jun 28, 2020; Published: Sep 25, 2020; Paper Id.: IJMPERDJUN20201423

\section{INTRODUCTION}

To establish a concept of development is necessary to circumscribe elements of thought and action of the human being, since the different interactions of the same are the determining elements of personal and social welfare towards growth (González-Bautista \& Arévalo Lara, 2020, p. 33). In this sense, an integrating vision must be carried out that brings together elements of a biotic and abiotic nature, as well as their interactions with the human (De la Peña Consuegra \& Centeno, 2020, p.8), given that the axes that trace the different positions of development, that some think from the local level, determine that antagonisms for the appropriation of the territory are framed in a certain space; Unleashing an evolution of the area in a period of time marked by volitional and collective actions resulting in production factors of different intensity (Calvo Palomares, et al, 2020, p. 21). The above is structured in the innumerable power relations that are exercised by the mediation of the geographical space, being the essential component that will define the development strategy to be implemented (Gallego, 2020, p. 7). To which, the scheme is linked to the territory, exercising a transforming role, establishing itself as a tactic for the use of the environment through collective acts, but which are directed by dominant actors or agents. Establishing high production as a strategy, which would allow achieving both peace and progress for the regions, whether remote or connected to urban centers (López, et al, 2020, p. 245). Being rooted in Latin America 
through the interference of the first world countries, that is, their growth is subject to the evolution of policies imposed by them (de Oliveira \& Sobrinho, 2020, p. 5); involving the role of local labor as a basis in the processes necessary for productivity (González, et al, 2020, p. 146). It can focus, from the geospatial field, to development in: local, national and global; showing how locally is expressed specifically the population's response to the consequences of national or international structural approaches (Mora \& Martínez, 2018, p. 33).

It can be specified that it is an internal subregional process, which aims to optimize local interactions for the purpose of growth; establishing as a premise the improvement in quality of life and inclusion of the population (Martín, 2018 , p. 6). In accordance with the above, it is assumed as the potentiation of local resources that point to a growth conducive to well-being by the transfer of resources (Jover, et al, 2016 , p. 232) ; in such a way that it places the territory as a competitive advantage, from the point of view of both biological and cultural diversity that allow differentiating actions in products and services (Medina, et al, 2019, p. 123), highlighting the value of ecosystem services as endogenous elements or qualities that when coming into play with an inclusive development model allow the positive transformation of the territory. Adding that, Local Development focuses on scaling welfare standards through the economic, since the efficient organization of local producers allows greater competitiveness, which must be supported by the social values reflected in the communities (Fernández \& Arrieta , 2020, p. 12); establishing that for the success of the model the participation of the state is necessary as support in social and territorial improvement with a strong link with municipal governments (Peláez Díaz, et al, 2020 , p. 14); In short, what Local Development seeks is to potentiate the territories through concrete actions in terms of productivity that mark occupation for the population present in them (Velásquez, 2020 , p. 180).

The present work tries to show in terms of local development the repercussion of the subtraction of territories for conservation for the purposes of production, storage and distribution of water. What it has been the historical community process, its impacts, to generate a prospective analysis of the rural community in the San Juanito municipality.

\section{MATERIALS AND METHODS}

Open and personal interviews were carried out, since they constitute an instrument of qualitative context that allows establishing contact with the members of the community in order to know the particular situation or the problem from the perspective of agents and actors; for (Patton, 1980, p. 100) "the objective of the qualitative interview is to know the perspective and the frame of reference from which people organize their environment and guide their behavior"; thus, their perceptions were established with the different actors. This tool was framed as determined by Fals -Borda (1985, p. 44) in the Participatory Action Research (IAP) approach: it is based on the inclusion of the researcher in the study area, so that he can observe and collate the physical, social, cultural, moral, historical and political characteristics of the object of study. We worked with the "agents of change" (Balcázar, 2003, p. 61), to finish a process: first: analysis of the historical conditions of the group or community, functional analysis of current conditions, participatory needs assessment; second: circles study; third: model for the development of community capacity (Fawcet, et al, 1985 ; Freire, 1973; Balcázar , et al, 1997).

For purposes of this work, and taking into account that the information collection tool was the interview, was developed the mentioned research stages with informants developing descriptors -stories research experiences and meanings- also throwing their perspectives, as represented in the following Figure 1: 


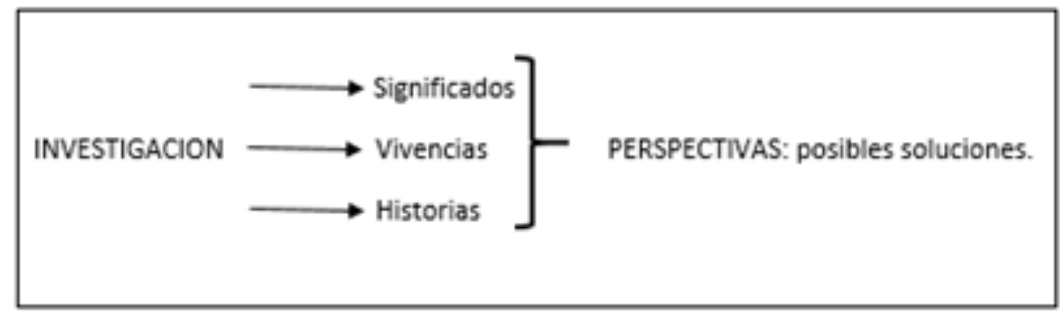

Figure 1: Central Activities of Participatory Action Research, adapted by the author, from Fals -Borda (1985) .

\section{RESULTS}

The recognition of anthropic influence from the social, economic and cultural aspects is necessary to establish the conflicts or pressures exerted in the territory; this with a view to defining the position of the community, both the one that lives there and the one that benefits from the environmental services provided by it. The San Juanito municipality is immersed in a high percentage in the Protected Area $(\mathrm{PNNCH})$ and another high percentage in the basin areas of the multiple rivers that have their genesis there. Thus, a great territorial insertion is observed in excluded areas and a diversity of coexisting expressions ranging from economic production, settled populations, such as the immanence of the rural. In the Municipality there are urban and rural type human settlements, which have survived from remote times and have derived their livelihood from the exploitation of its resources; These populations - through the different contacts with the territory — have generated symbolic and material elements that determine customs, thus defining the San Juanera culture as a product of observation and experience with the environment as well as the different techniques introduced for the exploitation of its resources.

It is added that the strongest relationship with the territory in Protected Areas is the use for livestock; permanent occupation is not generalized, and despite the fact that there are large properties, the common properties are smallholdings with few resources and limited access to technologies and markets (Molano, 2002 p. 76).

The anthropic intervention of the area dates back to pre-Hispanic periods; the occupation in the Colombian moors in the last century has been generated by dissimilar variables that have forced not very friendly relations with the ecosystem. The propensity for national development and conservation have been antagonistic, with both resources and the social component being the most affected in these processes; the legislative burden, which some cases protect and others favors exploitation, has not been an effective tool for sustainability, understood social, economic and environmental dimensions, since it favors the protection of some while neglecting others.

The most recent settlements date from the beginning of the 20th century. This is the case of San Juanito municipality, where the population density is low and they are predominantly rural "presenting some dynamics of smallfarm properties, although there are extensions of farms larger than 500 hectares in the areas of the Chingaza National Natural Park" (IGAC , 2012, p. 107); As can be seen, there are landowner processes in a lesser proportion, and preponderant smallholdings, establishing in the area overlapping social processes of old data that led to the generation of various environmental conflicts, as well as land tenure with processes of appropriation close to the century.

It should be noted that the reference area was established as a National Natural Park through Resolution 154 of 1977; that due to its position and water production, the Chuza reservoir was built in 1992 (PNN, 2005, p. 3), creating institutional components that affect the population present in this territory. In addition to the above, the creation of 
Resolution 710 of 2016 in which the limits of the Chingaza fell are defined, establishing the expansion of protection areas in the municipality where $63 \%$ of the population is rural and the properties are in a number 677; It is added that the properties have de- globes and de facto holdings that create a greater number of them (EOT, 2001 p. 12).

It should be noted that land management is subsistence, in most cases, with deficient technical elements and that does not correspond to the management of protection zones. This is the current panorama in the territory of the Chingaza fell inserted in the San Juanito Municipality, considered the pantry of $80 \%$ of the water of the city of Bogotá and which feeds $90 \%$ of the Orinoco basin, a strategic regional enclave and provider of the urban nucleus with the highest population growth and the largest in the country.

Within the information collected through the experiences and stories related and interpreted, it was established that at the beginning of the 20th century - the time when human settlements were created in the study area - the cutting and burning of forest was widespread, both for firewood consumption and construction, as well as for clearing land for extensive livestock farming and, to a lesser extent, agriculture; This is how the families were formed that are still present in the municipality, represented in new generations.

Livestock is consolidated as the main economic activity in the area, while agriculture was conceived as a selfconsumption action with a high presence of hunting; As of the seventies, as indicated in the rules above, the vocation of the territory changed when it was established as a Protection Area, creating limits in the exploitation areas; Subsequently, the process of change in the economic vocation arises from the entry of bean production, displacing livestock, which came to occupy high protected areas, since given the profitability of bean planting the spaces used in livestock passed to its production.

Furthermore, the intensive use of natural resources decreased due to the presence of environmental authorities in the area, with National Parks, CORMACARENA, being the agents in charge of controlling the use of ecosystem services provided in their jurisdictions.

In relation of the entrance of the agents in the jurisdictions determined by the Law, conflict is created since the population by tradition made a use that for them was normal of the existing resources, without any type of restriction, permission or concession; It should also be mentioned that the actions of these agents are late, since the area had for decades the presence of armed groups that did not allow institutional entry; This situation creates a greater clash with the community since in the near past sanctions for the improper use of natural resources were not required, much less imposed.

So far, a description has been made regarding the characteristics of a territorial nature and what has been the role of the actors and agents in the area. It should also be said that, due to the geographical and orographic location of the territory, the communication routes are deficient, being the airway the main means of communication until 25 years ago, which was a limitation for commercial exchange.

At the same time - for a better understanding of the local phenomenon-, it was established that the territorial vocation is agricultural with small livestock farms with land in areas available for exploitation and others in areas of restricted use that are nevertheless usufruct; due to the frequent use, in addition to the soil characteristics, a decrease in the quality of the soil is observed since the application of amendments is frequent. Due to the type of agricultural cultural practices, labor is required in a high percentage of the process, with scarce ones occurring in some peaks; This phenomenon has generated that the young population is motivated to work since, due to the high frequency of this, it 
allows them a high rate of income, creating abandonment or suspension of studies at the level of Middle Education. On the other hand, the San Juanero cultural roots are permanently mentioned, constituting a highland identity with immaterial elements and observable materials in the community, which allow it a complex cohesion that has been dynamic and has responded to the different changes in the environment, but that allows a reference line for its inhabitants with its territory.

Regarding the limitations permanently expressed by the informants - about the road infrastructure for bean extraction as well as the entry of inputs - it is observed that there is a constant feeling of abandonment in community support by the municipal authority, as well as the departmental one; in turn, in the property study carried out, the great weakness is the lack of titling as well as the factual partitions that put the population at a disadvantage in the face of negotiation processes or possible expropriations. On the other hand, the dependence on a monoculture, as well as the lack of foresight reflected by the community, becomes limiting since hopes for a constant extraction are established without observing the impacts caused in the medium and long term in the territory. There is no response to alternative regional production paths; These have been given by market demands and not by community planning, still less by the institutionality whose representativeness in this case has been coercive and punitive, generating rejection between the community and the environmental authorities.

\section{CHALLENGES FOR DEVELOPMENT}

Next, a description is made of the findings against the areas that are immersed in protection zones, and what is the position of the owners of these properties against the exploitation carried out in them.

Considering that the territory subject to study is immersed in a protection zone, and in accordance with national legislation regarding National Natural Parks, any type of exploitation of the same is prevented; The communities face the first obstacle after the creation of the Chingaza National Park, since it is within the Park's polygon, a situation that led to a decrease in the use of these properties, presenting only extensive livestock exploitation and low-scale forest exploitation. For this reason, the permanence of the owners or tenants in these lands is temporary, depending on the work to be carried out on them, making periodic visits regarding maintenance of boundaries, pastures, as well as bovine animals in breeding and fattening, observing depopulation of the zone.

In accordance with the above, an environmental order conflict is generated due to the subtraction of land, since on the date of the resolution to create the Park, no prior communication was required from the community, creating a clash between the environmental authority, National Natural Parks, the Aqueduct and Sewer Company of Bogotá, who manages and administers the water system within it, with the community present in the area; It is necessary to emphasize that the conflict has been dormant because the area was a guerrilla stronghold, thus preventing any type of state action against the residents. Currently, the environmental authority $(\mathrm{PNNCH})$ made a park management plan for the next five years, starting in 2016, where it conducts property studies as well as prioritizes the properties for a possible purchase agreement; Another feature of the plan is the determination of an area with a buffer function subject to the main ecological structure of the Park, which will further limit land uses depending on the location and characteristics of the ecosystem; the population in general is unaware of this project and therefore it will be a new focus of conflict since the area of agricultural exploitation will be reduced or its use will be limited.

In addition to the aforementioned, and due to the characteristics of the Protection Zone, there is a purchase plan for properties inserted in it. The difficulty is in the legalization of property, since most of them present or prove possession 
and not registered public deeds, which is why the goods cannot be sold, thus reducing the alternatives for the owners of properties in the area in terms of possibilities of concerted negotiation or payment for rights to land ownership. In this way, a negative panorama is presented for those who are inside or connected to Protection zones, since due to the processes of displacement of groups outside the law, the presence of environmental authorities has been reactivated; therefore, the pressure towards the community will be greater in the next five (5) years in front of the fulfillment of the Law in zones of economic exclusion, being the expropriation the legal action that takes place in this type of conflict. On the other hand, a land legalization program could be applied in favor of acquiring them, but some type of political will or action is not in sight.

\section{CONCLUSIONS}

The big challenge for this community is productive restructuring as an alternative to survival in the territory, given its characteristics; San Juanito is a municipality with some physiographic elements that establish in it some biodiverse characteristics with ecosystems of such complexity, that they turn it into a strategic zone of national and world order, added to this, the cultural wealth reflected in the appropriations and interactions with the Ecosystem services. These relationships are made in soils of high fragility due to the orography of the sector, subject to high pressures that make them vulnerable to degradation. All this associated with agricultural and forestry extractions strongly linked to conservation areas, thus determining the pressure, status and management of the resources immersed in these soils, thus establishing the productivity of the different related systems.

Likewise, talking about reconversion in the municipality is a transformation of the technological, economic, social, and cultural order, which transcends the transition from conventional to sustainable socio-ecosystems, immersed in associative systems, market transformations and production diversification, as well as travel services. This is an alternative since, being located in strategic ecosystems, they become a strength for both conservation and productivity, since the yields per unit area and their carrying capacity tend to rise, being intensive and sustainable.

Adding to the above, greater efficiency in production, such as a decrease in forest use, enriching the soil, liberating exploitation areas for conservation, and generating connection corridors between protection and buffer zones, such as biological corridors. This reconversion process must consider a strong tourist component since this vocation, by Law of the Protection Zones, is allowed associated with a vernacular tourism that would allow an exploitation of the San Juanera culture.

Therefore, the community present in protection territories has competitive advantages for their permanence; This will be achieved with institutional as well as community support, allowing a comprehensive development panorama.

\section{REFERENCES}

1. Balcázar, F. (2003). Investigación Acción Participativa (IAP): Aspectos conceptuales y dificultades de implementación, Fundamentos en Humanidades, 4 (7-8): 59-77.

2. Balcázar, F. E., Seekins, T. \& Fawcett, B. (1997). El Involucramiento de Consumidores en Organizaciones de Lucha por los Derechos: Guía Para la Planeación de Proyectos de Acción. Institute on Disability and Human Development, University of Illinois at Chicago.

3. Calvo Palomares, R., Sigalat Signes, E., \& Aguado i Hernàndez, J. A. (2020). La descoordinación territorial del desarrollo local: ¿ demasiados actores para un mismo territorio? Una aproximación empírica a la realidad de la Comunitat Valenciana. 
4. De la Peña Consuegra, G., \& Centeno, M. R. V. (2020). Acercamiento a la conceptualización de la educación ambiental para el desarrollo sostenible. Revista Cubana de Educación Superior, 39(2).

5. de Oliveira, R. D. S., \& Sobrinho, M. V. (2020). Gestión de Políticas Públicas para el Desarrollo Local en Brasil. GIGAPP Estudios Working Papers, 7(140-149), 1-22.

6. EOT-Esquema de Ordenamiento Territorial. (2001). Acuerdo Esquema de Ordenamiento municipio de San Juanito. Esquema de Ordenamiento Territorial. http://cdim.esap.edu.co/BancoConocimiento/S/san_juanito___meta__eot___2001/san_juanito__meta_-_eot_-_2001.asp

7. Fawcett, S. B., Seekins, T., Balcazar, F. E. (1985). Consumer involvement in advocacy organizations: Leading action oriented meetings - Volume, II. Lawrence, Kansas: Research and Training Center, University of Kansas (USA), M-12.

8. Fals Borda, O. (1985). Conocimiento y poder popular. Bogotá: Edit. Siglo XXI. Bogotá D.E. p. 172

9. Fernández, D. R. R., \& Arrieta, M. P. B. (2020). Capital social y desarrollo local: El caso del Proyecto Fitekantopus en el Barrio Cultural de La Balanza-Comas (Doctoral dissertation, Pontificia Universidad Catolica del Peru-CENTRUM Catolica, Perú. Pp. 1-23.

10. Freire, P. (1973). Education for critical consciousness. NY: Continuum.

11. Gallego, D. R. (2020). El hábitat y el desarrollo local en Cuba. Revista Científica Cultura, Comunicación y Desarrollo, 5(2), $6-10$.

12. González-Bautista, $M \&$ Arévalo-Lara, E. (2020). Crecimiento económico y bienestar Social y Ambiental. construcción del indicador de bienestar económico sostenible en América Latina, período 2000-2018 (Bachelor's thesis, Universidad Nacional de Chimborazo.

13. González, E. G. F., Trujillo, A. M. G., González, A. P., \& Curiel, J. A. B. (2020). Potencialidades de la población económicamente activa (PEA) para el desarrollo local. Gestión de las organizaciones: Nuevos enfoques y aplicaciones. P. 190

14. IGAC. Instituto Geográfico Agustín Codazzi. (2012) Atlas de la distribución de la propiedad rural en Colombia/El Instituto. Bogotá: Imprenta Nacional de Colombia.

15. Jover, J. N., Marrero, I. A., Quiñonez, A. A., \& Alfonso, G. F. (2016). Educación superior, innovación y desarrollo local: experiencias en Cuba. In Congreso Universidad (pp. 228-248).

16. López, M. I. R., Hernández, J. A. E., Quiñonez, R. E., \& García, R. R. M. (2020). aproximación teórica y aplicada al modelo de diversificación integral de cultivos para el desarrollo agrícola y económico en el Cantón Quinindé, provincia De Esmeraldas, República Del Ecuador. Mikarimin. Revista Científica Multidisciplinaria. e-ISSN 2528-7842, 6, 241-258.

17. Martín, J. C. (2018). Desarrollo local en los espacios rurales. Polis Revista Latinoamericana, (2).pp. 1-15

18. Medina, C. A. H., Hernández, A. B., \& Fuentes, M. A. C. (2019). Sistemas de innovación y formación de redes para el desarrollo local. Ciencia e Interculturalidad, 24(01), 121-129.

19. Molano, J. (2002). Los páramos producción social del espacio de las altas montañas ecuatoriales. Congreso Mundial de Páramos, Memorias. Paipa, Boyacá.

20. Mora, M. J., \& Martínez, F. R. M. (2018). Desarrollo local sostenible, responsabilidad social corporativa y emprendimiento social. Equidad y desarrollo, (31), 27-46.

21. Patton Q. (1980). Qualitative Evaluations Methods. Beverly Hills. C.A. Sage Publications. 
22. Peláez Díaz, G., Castillo Picón, J., \& Manrique Cáceres, J. (2020). Desarrollo local y gobiernos locales de Ancash 20102014: una aproximación a su desempeño. Universidad Nacional Santiago Antúnez de Mayolo, http://repositorio.unasam.edu.pe/handle/UNASAM/3739.

23. PNN. (2005). Plan estratégico y de manejo del Parque Nacional Natural de Chingaza 2005-2009. Parques Nacionales Naturales. Bogotá D.C. (Colombia).

24. Resolución 710 (2016). https://www.ambienteysociedad.org.co/resolucion-0710-de-2016-que-delimita-el-paramo-dechingazal

25. Velásquez, D. (2020). Empoderamiento Personal y Social de los jóvenes del valle Santa Catalina de los Distritos Poroto, Simbal y Laredo de la provincia de Trujillo y el desarrollo local. Revista Ciencia Y Tecnología, 16(1), 177-188. 